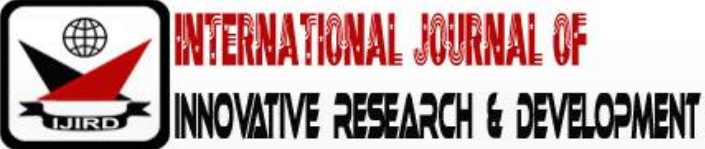

ISSN 2278 - 0211 (Online)

\section{Teachers' Characteristics and Student Competence on Achievement in Computer Studies, in Cross River State, Nigeria}

Dr. Ofem Ubi Arikpo
Institute of Education,
University of Ibadan, Ibadan, Oyo State, Nigeria
Ndem, Major
Lecturer, Department of Environmental Health,
College Of Health Technology, Calabar, Nigeria
Ayam, Anthony Agbajor
Senior Lecturer, Department of Community Health,
College of Health Technology, Calabar, Nigeria
Obo, Ekpenyonganwan Ayi
Senior Lecturer, Department of Community Health,
College of Health Technology, Calabar, Nigeria
Isaac Rajunor Bassey
Senior Lecturer, Department of Computer Science,
College of Health Technology, Calabar, Nigeria
Dr. Eze A. Eze
College of Health Technology, Calabar, Nigeria
Senior Lecturer, Department of Health Information Management,

\begin{abstract}
:
Teaching and learning of Computer Studies requires new approaches to develop in students, reasonable level of competence in the use of computer. Available literature shows that most studies over the years focused on the use of computer resources in teaching and learning, with only a few addressing teacher's factors and students' competence. This study therefore, examined teacher characteristics and competence of students on achievement in Computer Studies. Survey design was adopted. Simple random sampling was used to select Ikom and Calabar education zone. Purposive sampling was used to select 41 schools (Ikom-21, Calabar-20). From each selected school, JSS 1, 2 and 3 students were randomly selected. A total of 2,127 students and 63 Computer Studies teachers participated in the study. A Teachers' Computer Competence Questionnaire (TCCQ) $r=(0.74)$; Students' Computer Competence Questionnaire (SCCQ) $r=(.83)$ and Computer Studies Achievement Test (CSAT) for JSS 1, 2 and $3(r=76, r=82$ and $r=78$ ) were used for data collection. Data were analysed using descriptive statistics and multiple regressions at 0.05 . Forty-four percent of the teachers qualified in teaching Computer Studies. The three variables jointly predicted student' achievement in Computer Studies $\mathrm{F}(3,2110)=19.464, P<0.05$, while Teachers Competence $\left[\beta=-.041, \mathrm{t}_{(2110)}=1.979, p<.05\right]$ and Student Competence $[\beta=-.133$, $\left.\mathrm{t}_{(2110)}=6.372, \mathrm{p}<05\right]$ were the most significant and persuasive variables in predicting students' achievement in Computer Studies. Hence, for teaching of Computer Studies to be effective, teachers and students' competence should be improved on.
\end{abstract}

Keywords: Teacher qualification, competence, student competence and achievement in computer studies

\section{Introduction}

The teaching and learning of Computer Studies requires new educational approaches to face societal challenges. Teachers no longer depend on traditional ways of imparting knowledge to students, which led to the emergence of new forms of teachers in respect to qualification and competence in the classroom. Conversely, in the global world, computer use is gaining popularity in recent years with a huge influence on improvement of students' analytical skills, promoted creativity and stimulated learner centred learning opportunities in the educational system. The introduction of Computer Studies in Nigerian schools is aimed at developing in students' reasonable level of competence in the use of computer and other ICT facilities. Children are expected to be equipped with new skills and to develop competence in them to a 
reasonable extent, in order to survive in the world of work. Arikpo (2017) holds the opinion that the idea of Computer Studies in the Nigerian educational system is to provide opportunities and challenges to teachers and students, for progress in the teaching and learning processes.

In the same vein, Adebayo in Adefunke, Ayodele and Olufemi (2014) maintained that in this new age of information explosion, every average individual wants to explore the information system, which makes Computer Studies very important subject to every individual and for national development. Yusuf (2005) established that the benefit and impact of computer to the individual and the society make Computer Studies an essential part of the educational system. Similarly, the federal government of Nigeria as a matter of priority hopes to meet up with the standard of what is happening around the world with respect to the new technological development. The involvement of Computer Studies into the school curriculum is the needed tool for survival and as activity every child should be exposed to in order to achieve her stated objective in the new era is very paramount.

Nigerian Educational Research and Development Council (NERDC, 2007) and the United Nations (UN, 2005) specified that the introduction of Computer Studies education in the school system is one of the approaches that aimed at changing classroom teaching and learning process. The Federal Government of Nigeria acknowledged the role of Computer Studies as an innovation for attaining Millennium Development Goals (MDGs) and Education for All (EFA). Hence, this necessitated the inclusion of Computer Studies as part of the curricula that every Nigerian child should be exposed to, starting from the basic level of education (Arikpo, 2017).

In view of this, the importance of Computer Studies in most fields of human endeavours cannot be underestimated especially when one considers its usefulness in science and technology. The use of technology during the early years in classrooms holds a lot of benefit for teachers, students as well as parents. Computer Studies as used in this study refers to the process of teaching children the basic concepts relating to a computer and its operations as well as knowing the basic components of a computer system. Computer Studies in schools signify the use of computers, telecommunication devices and cables to transfer information to the students. This type of technology has provided quite a number of new opportunities for schools to harness and use Computer Studies facilities to support and complement teaching and learning process using a curriculum. Hence, the qualification of the teacher is an essential part of instruction in a school system.

In the same way, the quality of education of any nation could be determined by the quality of her teachers (Abe, 2014 \& Ndukwe, 2002). Teacher qualification is concerned with what they are made of in their new teaching profession, considering their level of experience, certification and other instructional behaviours that aid the child to learn better. Abe and Adu (2013) and Abe (2014) hold the opinion that qualified teachers are those who have academic training as a result of enrolment into educational institution and have obtained qualifications such as HND, BSc, B. Ed, NCE etc. while professionally qualified teachers are those who have registered and have obtained academic training in a subject that gave knowledge, skills, technique different from the general education ( Abe, 2014). Furthermore, Goldhaber (2003), Olatoye (2006), Bhaskar (2002) and Akinsolu (2010) assert that teachers' qualification has a significant effect on students' academic achievement, and their level of competence may be valuable in applying the skills gained by the students. Effandi and Zanaton (2007) suggest that the quality of education that teachers provide to learners is highly dependent upon what teachers do in the classroom, which means, in preparing children to become successful individuals tomorrow, teachers need to ensure that their teaching is effective by ensuring how children learn and confirming what approach to use with the available resources that will prove their competence.

Competence as one of the variables in this study refers to abilities that require an individual's knowledge and skills to accomplish a stated task in an educational program. Teachers who lack adequate mastery of their subject area and who are not well informed about the developments in their subject area will have little or nothing to offer to learners (FRN, 2004). Knezek and Christensen (2002) assert that teachers' competence with computer technology is a key factor for effective teaching of Computer Studies. Teachers' competence in this study refers to the new ability of teacher to apply varying terms of their knowledge of content of instruction and classroom practices in the selected topics from Computer Studies. Teacher competence in Computer Studies empowers instructors to use computers in a fundamental way while dealing with students.

The effectiveness of teachers in teaching Computer Studies in school could be determined by the quality of training undertaken by the teacher at all levels. For instance, Kathleen (2010) established that in most primary schools in Australia, children go off with a specialist teacher to a computer laboratory one hour in a week for their Computer Studies lesson. With this, many teachers have felt satisfied that Computer Studies syllabus was being "covered" by the weekly specialist classes, while many classroom teachers lack confidence and skills as expected in teaching. Westera (2001) is of the view that competence of teachers is revealed when they have the ability to master complex situation that goes beyond knowledge and skills of the subject matter and could be applied in the learning process. In recent time, literature has shown that academic achievement is determined by many variables, including teacher qualification, competence and students' competence, among others (Aremu \& Sokan, 2003).

Besides, achievement in Computer Studies has been a matter of great concern not only to parents but also to stakeholders like as: Teachers, School Administrators as well as Policy Makers, etc. Their concern in the society is to see that, activities in school account for the achievement of students at all levels. This implies that if parents, government and teachers fail to perform their duties as expected in the education of the child, it is likely to affect students' level of achievement and educational objectives (Yusuf \& Afolabi, 2010; Tekos \& Solomonidou, 2009). Accordingly, the Federal Republic of Nigeria (FRN, 2004), maintains that Nigeria educational philosophy must be capable of encouraging independent thinking on the part of the teacher, to inculcate into the learners the ability to tolerate the views and feelings of others as well as have respect for dignity and labour. 


\section{Research Questions}

As go guide to this study, the following research questions were formulated and answered:

- What is the profile of computer studies teachers in upper basic level of education with respect to Teacher qualification?

- To what extent would the three predictor variables (Teacher qualification, Teacher competence and Student competence) when taken together predict student academic achievement in Computer Studies?

- What are the relative contributions of each of the three factors (Teacher qualification, Teacher competence and Student competence) when taken together predict students' academic achievement in Computer Studies?

\section{Methodology}

\subsection{Population and Sampling procedure}

The study adopted survey research design type. The population comprises upper basic level students (1, 2 and 3) in public schools and their computer studies teacher. Multi-stage sampling procedure was used to select students used for the study. First, simple random sampling technique was used to select Calabar and Ikom education zone. Purposive and Proportionate to size sampling techniques were used to select 41 schools (21 from Ikom and 20 schools from Calabar education zone). Furthermore, from each of the selected schools, an arm each from upper basic 1, 2 and 3 were randomly selected. All the students in the selected classes responded to the questionnaires and were retrieved with the help of teachers and a research assistant. In all, 123 classes, 2127 students as well as 63 computer studies teachers were used. Sixty-three teachers were used because in some schools, only one computer teacher taught the three levels.

\subsection{Instrument}

The study made use of three different valid and reliable instruments constructed by the researchers. First, Teachers' Computer Competence Questionnaire (TCCQ) was developed by the researcher to elicit information on extent of competence of teachers. The questionnaire initially has 30 items which were reduced to 20 items after validation, placed beside two scales of Competence $(\mathrm{C})$ and not Competence $(\mathrm{NC})$, in which the respondents were requested to indicate their level of agreement. The instrument was validated with a reliability coefficient index of .74 .

The next instrument is Student Computer Competence Questionnaire (SCCQ). This instrument initially had 25 items presented beside two response format scale of Competent $=\mathrm{C}$ and Not Competent $=\mathrm{NT}$. The scale had 21 items after validation with reliability coefficient index of .83 while Computer Studies Achievement Test (CSAT), initially had 40 items, developed to elicited information on student achievement in Computer Studies with four option of A, B, C and D. The face validity of the instrument was established by three (3) experts in Educational Evaluation and other two (2) specialists in item construction in Faculty of Education. The reliability of the achievement test was determined using Kuder Richardson (KR-20) formula that yielded a coefficient index of 0.76 for JSS1, 0.82 for JSS 2 and 0.78 for JSS 3 . Descriptive statistics frequency and percentage were used to indicate the number of responses to each item, while multiple regressions were used to predict student achievement in Computer Studies.

\section{Results and Discussion}

\subsection{Profile of Computer Studies Teachers in Upper Basic Level of Education with Respect to Teacher Qualification}

\begin{tabular}{|c|c|c|}
\hline Teacher Qualification & Frequency & Percentages (\%) \\
\hline NCE & 8 & 12.7 \\
\hline B.SC & 28 & 44.4 \\
\hline B.A & 8 & 12.7 \\
\hline B.ED & 12 & 19.0 \\
\hline HND & 7 & 11.1 \\
\hline Total & 63 & 100.0 \\
\hline
\end{tabular}

Table 1: Profile of Computer Studies Teachers by Educational Qualification

Table 1 reveals the educational qualification of the teachers. The result shows that 28(44.4\%) of the respondent have Bachelor Degree in Science (B.sc), 12(19.0\%) holds Bachelor Degree in Education (B.ed), those with Bachelor in Arts (B.A) and National Certificate of Education (NCE) have 8(12.7\%) while 7(11.1\%) have Higher National Diploma (HND). Furthermore, majority of the teachers used $43(68 \%)$ do not have any form of teaching qualification whereas only 20(32\%) of the teachers do. This implies that teachers who teach Computer Studies are not professionally qualified. Thus, teaching of any subject at the upper basic level of education requires those who have obtained certificate/ training at the tertiary institution. The findings of this study lend credence to earlier findings of Abe (2014) who established that professionally qualified teachers are those who have academic training in a subject that gave knowledge, skills, technique different from the general education. The study further reveals that majority of the teachers were trained graduates with minimal impact in respect to their professional qualification. Tella (2008) and Olatoye (2006) assert that a teacher who doesn't have both the academic and professional teaching qualification would certainly have negative influence on the teaching-learning of his/ her subject. Hence, a well-trained teacher is influence by his qualities of teaching, handle the courses effectively, have 
the ability to interpret the curriculum and building cognitive ability of the child by passing the appropriate knowledge to the students.

4.2. Extent to Which the Three Predictor Variables (Teacher Qualification, Teacher Competence and Student Competence) When Taken Together Predict Student Academic Achievement in Computer Studies

\begin{tabular}{|c|c|c|c|c|c|}
\hline \multicolumn{2}{|c|}{ Variable } & ST_A & TQ & TC & SC \\
\hline Student Achievement & 1.000 & & & \\
\cline { 2 - 6 } & Teacher Qualification & .006 & 1.000 & & \\
\cline { 2 - 6 } & -.041 & -.027 & 1.000 & \\
\hline Teacher Competence & -.127 & .006 & -.022 & 1.000 \\
\hline Student Competence & 15.54 & 2.72 & 2.31 & 31.69 \\
Mean & 3.480 & 1.226 & .691 & 5.558 \\
\hline
\end{tabular}

Table 2: Correlation Matrix of Variables

ST. A=Student Achievement, TQ=Teacher Qualification, TC=Teacher

Competence, $\mathrm{SC}=$ Student Competence.

$*=$ Significant at $\mathrm{p}<0.05$

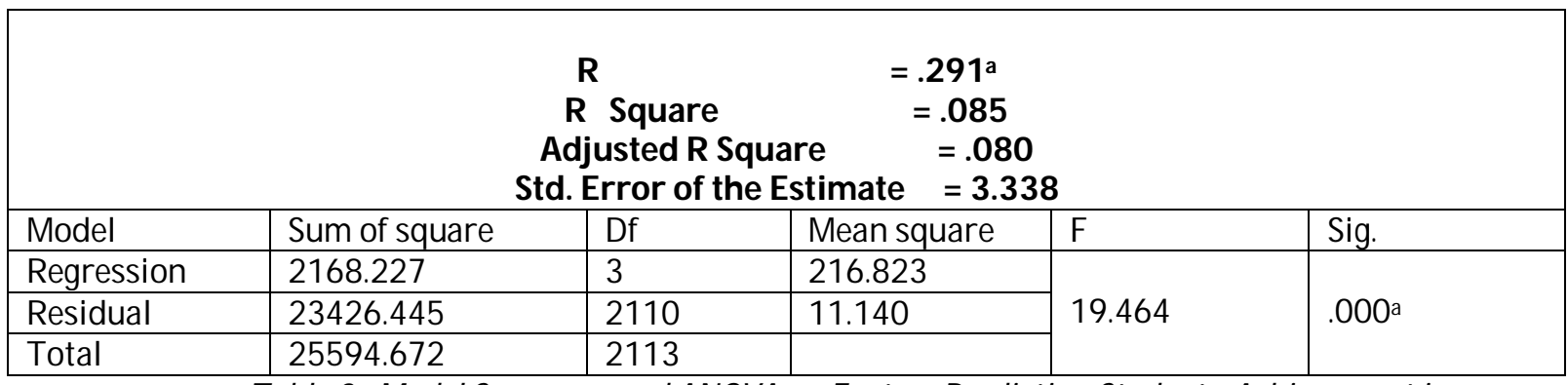

Table 3: Model Summary and ANOVA on Factors Predicting Students' Achievement in

a. Computer Studies At The Upper Basic Level Of Education.

Predictors: (Constant), Teacher Qualification, Teacher Competence and Student Competence.

$*$ Significant at $\mathrm{P}<0.05$

b. Dependent Variable: Achievement in Computer Studies

Table 2 indicates the summary of data analysis on the test of relationship between the three independent variables. The result reveals that there is an inter-correlation between students' competence and achievement of students. Pointing out that students' high achievement should be traced beyond their competence. Using the regression analysis, it is shown on Table 3 that the three predictor variables when taken together allow reliable prediction of the criterion variable (Achievement in Computer Studies). The result also, reveals that the value of the coefficient of Multiple Regression is (R) $=.291 *$, Multiple Regression Square $\left(\mathrm{R}^{2}\right)=.085$ and the adjusted squared multiple correlation $\left(\mathrm{R}_{\mathrm{adj}}\right)=.080$. The model has a positive and high correlation with a variance of .085 . This implies that $8.5 \%$ of the total variation of achievement in Computer Studies is attributable to the combined contribution of the predictor variables built into the regression model.

The result further shows that $\mathrm{F}(3,2110)=19.464, \mathrm{p}<0.05$ jointly allow for a reliable prediction of student achievement in computer studies. The result also reveals that the standard F-test that examined the relationship between the predictor variables and the criterion variables are linear and significant $(\mathrm{p}<05)$. Thus, the model predicted significantly the achievement of upper basic level students in Computer Studies.

\begin{tabular}{|c|c|c|c|c|c|c|c|c|c|c|}
\hline \multirow[t]{2}{*}{ Model } & \multicolumn{2}{|c|}{$\begin{array}{c}\text { Unstandardized } \\
\text { Coefficients } \\
\end{array}$} & \multirow{2}{*}{$\begin{array}{c}\begin{array}{c}\text { Standardized } \\
\text { Coefficients }\end{array} \\
\text { Beta } \\
\end{array}$} & \multirow[t]{2}{*}{$\mathbf{T}$} & \multirow[t]{2}{*}{ Sig. } & \multicolumn{2}{|c|}{ Correlations } & \multicolumn{3}{|c|}{ Collinearity Statistics } \\
\hline & B & $\begin{array}{c}\text { Std. } \\
\text { Error }\end{array}$ & & & & Zer-order & Partial & Part & $\begin{array}{c}\text { Toleranc } \\
\text { e }\end{array}$ & $\begin{array}{l}\text { VIF } \\
\end{array}$ \\
\hline (Constant) & 16.942 & 1.050 & & 19.405 & .000 & & & & & \\
\hline $\begin{array}{c}\text { Teacher } \\
\text { Qualification }\end{array}$ & .002 & .060 & .001 & .035 & .972 & .006 & .001 & .001 & .980 & 1.020 \\
\hline $\begin{array}{c}\text { Teacher } \\
\text { Competence }\end{array}$ & -.208 & .105 & -.041 & -.1 .979 & .048 & -.041 & -.043 & -.041 & .997 & 1.001 \\
\hline $\begin{array}{c}\text { Student } \\
\text { Competence }\end{array}$ & -.083 & .013 & -.133 & -6.372 & $.000^{*}$ & -.127 & -.138 & -.133 & .994 & 1.006 \\
\hline
\end{tabular}

Table 4: Summary of Relative Contribution of Factors Influencing Student Academic Achievement in Computer Studies at the Upper Basic Level of Education

a.Dependent Variable: Student Achievement 
Table 4 describes the Unstandardized Coefficients (B) and Standardized Coefficient (beta weight), $t$ value, $p$ values suggest that the predictor variables is having a large impact on the criterion variable, while the zero order, partial and part indices, the tolerance and VIF factors are the measure between the predictors variables and can vary between 1 and 0 , the closer to zero the stronger the relationship of the predictor variable. Also, V/ F is an alternative measure of collinearity (reciprocal of tolerance) in which a large value indicates a strong relationship between predictor variables. The tolerance statistics presented in the coefficient Table 4 indicated that all the predictor variables positively correlated among themselves and was tolerated in the model with a statistic range of .7 to .9. Table 4 also shows that the Beta ( $\beta$ ) weights specified that only two out of the three predictor variables contributed significantly to the prediction of students' achievement in Computer Studies. The two variables that contributed to the model are;

Students Competence $\left[\beta=-.133, \mathrm{t}_{(2110)}=-6.372, \mathrm{p}<.05\right]$,

Teacher Competence $\left[\beta=.-041, \mathrm{t}_{(20110)}=-1.979, \mathrm{p}<.05\right]$,

The observed beta value of the analysis indicates that for every one-unit change in students' competence and teacher competence, there is a corresponding increase of .041 and .133 in student Computer Studies achievement. Other variables such as teacher qualification, did not contribute statistically and significantly to the variance in the student achievement in computer studies. Hence, were students are equipped with required knowledge of computer; they are likely to do well in Computer Studies. The result of the study collaborates with the views of Kimani, Kara and Njagi (2013), who found out that teachers teaching qualification has no significant relationship with student achievement in various studies examined. Also, the finding suggested that students' performance in Computer Studies could be as a result of other factors than teacher qualification (Harris and Sass, 2008, Aaronson and Barrow and Sander 2007). In order word, the quality of materials provided in most of the schools will determined the level of students' achievement in schools. The findings suggested that students' performance in Computer Studies could be as a result of other factors than teacher qualification (Harris and Sass, 2008, Aaronson et al. 2007).

\section{Conclusion}

This study explores teachers' characteristics and student competence as predictors of student's achievement in computer studies in Cross River State. The findings of this study reveal that; the proportion of qualified computer studies teachers is not enough to meet up with the demand of schools. Further evidence yielded by the study reveals that majority of the students has not learnt sufficient practical to allow competence and knowledge acquisition. Hence the government is expected to motivate the teachers and schools by making sure that teachers are constantly train with new knowledge of computer in order to achieve her stated objectives.

\section{References}

i. Aaronson, D., Barrow, L. \& Sander, W (2007). Teachers' and Students' Achievement in the Chicago Public High Schools. J. Labor Econ. 25(1):95-135.

ii. Abe, T., O., \& Adu, E., I. (2013). Influence of Qualification on Development and Assessment of Computer Programmed Instructional Package on Energy Concept in Upper Basic Technology in Ekiti State, April J. Sci. Technol., 3 (6): 611-618.

iii. Abe, T. (2014).The effect of teachers' qualifications on students' performance in mathematics Sky Journal of Educational Research Vol. 2(1), pp. 010 - 014, February, 2014 Available online http:/ / www.skyjournals.org/ SJER ISSN 2354-4406 @ 2014 Sky Journals

iv. Aremu, A., O. \& Sokan, B., O. (2003). A Multi-causal evaluation of academic performance of Nigerian Learner, Issues and implications for National development. In Ayodele- Bamisaiye, O, I. A, Nwazuoke, \& A. Oladiran (Eds), Education this millennium (pp 365- 375). Ibadan: Macmillan Nig. Ltd.

v. Adefunke T., O. Ayodele T., S \& Olufemi A. E. (2014). An Assessment of Implementation of National Computer Education Curriculum in Nigerian Primary Schools: The 2014 WEI International Academic Conference Proceedings New Orleans, USA.

vi. Arikpo, O., U. (2017). Evaluation of Computer Studies' Curriculum Implementation at the Upper Basic level of Education in Cross River State, Nigeria. Unpublished Ph.D. thesis of Institute of Education, University of Ibadan.

vii. Akinsolu, A., O (2010). Teachers and Students' Academic Performance in Nigerian Secondary Schools: Implications for Planning. Florida Journal of Educational Administration \& Policy, Volume 3, issue 2.

viii. Bhasker, B (2002). Educating the educators: Self inquiries for parents and teachers. Journal of computer assisted learning 26(3), 175-189.

ix. Effandi, Z. \& Zanaton I. (2007), Promoting Cooperative Learning in Science and Mathematics Education: A Malaysian Perspective. Eurasia Journal of Mathematics, Science \& Technology Education, 2007, 3(1), 35-39 University Kebangsaan, Selangor, MALAYSIA Retrieved 3rd April 2013.

x. Edu, D., O. Edu, G., O., \& Kalu, I., M. (2012). Influence of Academic qualification on gender on teachers' perception of difficult concept in primary science in Ikom, educational Zone of Cross River, Greene \& Journal of Educational research 2(2). Retrieved from http: www.gjournals.org. On 2/ 6/ 15.

xi. Federal Republic of Nigeria (2004), National Policy on Education (Revised), NERDC Press, Lagos.

xii. Goldhaber, D., (2003). The mystery of good teaching: Surveying the evidence on student achievement. The Education Next Spring 2002 fine article http:/ / www.finderticles.com.

xiii. Harris, D., N \& Sass, T., R (2008). Teacher Training, Teacher Quality and Student Achievement." CALDER Working Paper 3. Washington, D.C.: The Urban Institute. 
xiv. Kathleen, M., (2010). Learning Information Communication and Technology skills Incidentally Geelong in Victoria, Australia.

xv. Knezek, G., \& Christensen, R (2002). Impact of New Information Technologies on Teachers and Students. Education and Information Technologies, vol. 7, no. 4, p. 369-376.

xvi. Ndukwe, P., N. (2002). School and Teacher factors as determinants of classroom materials resources Utilization in in pre-primary school in Lagos state. Unpublished Ph.D. Thesis, University of Ibadan, Ibadan, Nigeria

xvii. Nigerian Education Research Development Council (2007). The a-year Basic education curriculum at a glance. Lagos: NERDC Press.

xviii. Olatoye, R., N. (2006). Science Teacher Effectiveness as a predictor of students' performance in senior secondary school certificate exams. Journal of Educational Studies, 6, 104-110.

xix. Passos, A. (2007). Teachers competence and its effect on pupil performance in Mozambique and other SACMEQ countries- preliminary result presentation to SACMEQ Assembly of the minister's international institute for educational planning -UNESCO, Paris.

xx. Tella, A. (2008), Teacher variables as predictors of academic achievement of primary schools' mathematics. International journal of elementary education $1 ; 1 ; 16-33$

xxi. Tekos, G. \& Solomonidou, C. (2009). Constructivist learning and teaching of optics concepts using ICT tools in Greek primary school: A pilot study. Journal of Science Education and Technology 18.5: 415-428.

xxii. United Nations (2005). Millennium Development Goals Report. New York: United Nations Department of Public Information.

xxiii. United Nations, (2010). Millennium Development Goals Report (2010). www.en\person with Universal Basic Education Commission (2008). Training manual on the 9-year basic education curriculum. Abuja: UBEC.

xxiv. Westera, W. (2001). Competence in Education: a confusion of tongues. In journal of Curriculum Studies 33(!), (99 75-88).

xxv. Yusuf, M., O. (2005). Information and communication technology for education: Analysing the Nigeria policy for information technology. International Education Journal, 6(3), 316-321.

xxvi. Yusuf, M., O. \& Afolabi, A.O. (2010). Effects of Computer Assisted Instruction (CAI) on Secondary School Students' Performance in Biology. The Turk. Online Journal of Educational Technology 9(1):62-69. 